\title{
A study of the health of Malaysian plantation workers with particular reference to paraquat spraymen
}

\author{
J K HOWARD, ${ }^{1} \mathrm{~N}$ N SABAPATHY, ${ }^{2}$ AND P ANNE WHITEHEAD ${ }^{3}$ \\ From the Chemical Industries Association, ${ }^{1}$ London, Dunlop Estates Bhd, ${ }^{2}$ Malaysia, and Plant Protection \\ Division, ${ }^{3}$ ICI Ltd, Bracknell, UK
}

\begin{abstract}
Tests of pulmonary function (FVC, $\mathrm{FEV}_{1}, \mathrm{FEV}_{1} \%$, and single breath $\mathrm{CO}$ diffusion), renal function (serum creatinine and BUN), liver function (serum ALT, AST, and ALKP) and a full haematological screen were performed on 27 paraquat spraymen (mean spraying time $5 \cdot 3$ years; mean individual annual quantity of paraquat handled, $67.2 \mathrm{~kg}$ as paraquat ion) and on two control groups. One of the control groups consisted of 24 general plantation workers with minimal exposure to paraquat arising from occasional work in recently sprayed areas, and the second consisted of 23 latex factory workers with no known occupational exposure to paraquat. The results showed no significant differences as a consequence of occupational exposure to paraquat. Long-term paraquat spraying at the concentrations used produced no quantifiable harmful effects on health as measured by the indices selected for this study.
\end{abstract}

\begin{abstract}
Although paraquat has been in general agricultural use as a herbicide and desiccant since the mid1960 s, there have been only a few properly documented studies of the health of either sprayworkers or formulators using it. Swan, ${ }^{1}$ in a report on the health of sprayworkers in Malaysia, indicated that at spray strengths of $0.05 \%$ paraquat ion (equivalent to $1: 400$ dilution of the $20 \%$ agricultural concentrate) there was no significant hazard to the operator, either from local injury or systemic absorption. Further work on the individual exposure of spray operators carried out by Hogarty ${ }^{2}$ included an analysis of the droplet size distribution produced by standard knapsack "polijet" nozzles, a determination of the concentration of droplets of respirable size in the operator's breathing zone, and an estimation of the degree of potential skin contamination. He concluded that there was likely to be little hazard associated with normal agricultural use. Spray strengths used in this study were $0.5 \%$ and $0.25 \%$ paraquat ion (equivalent to $1: 40$ and $1: 80$ dilutions of the $20 \%$ concentrate), which represent the highest strengths recommended in the directions on the manufacturer's label.
\end{abstract}

Received 9 June 1980

Accepted 8 July 1980
Hogarty's conclusions were supported by the work of Staiff $e t a l,{ }^{3}$ which was designed to determine the potential exposure, both dermal and respiratory, of field operators using conventional low pressure power spray equipment and using a spray strength of $0.15 \%$ paraquat ion (equivalent to 1:133 dilution of the commercial concentrate). A survey of formulation workers in both Britain and Malaysia ${ }^{4}$ was unable to show any effects on general health or any important local problems even after several years of continuous daily exposure to paraquat in the formulating plants. Howard ${ }^{5}$ has recently reviewed the whole area of occupational exposure to paraquat.

Concern has been expressed, nevertheless, that the full extent of the potential hazard to sprayworkers has not been sufficiently explored. Claims have been made that generalised ill-health may result after working with paraquat ${ }^{6}$ and that the spraying of paraquat may represent an important health hazard. ${ }^{7}$ Thus it was decided to investigate the health of a group of sprayworkers in Malaysia who had done only herbicide spraying, using no other pesticides, and who used large quantities of paraquat for considerable periods. In an attempt to determine whether such long-term spraying has any measurable effects the spraymen were compared with two 110 
control groups. One was a group of general workers, some of whom may occasionally work in areas recently sprayed with paraquat, and the other a group of latex processing factory workers, who had received no known exposure to paraquat in the course of their work.

\section{Method}

\section{POPULATION}

The workers studied were drawn from six rubber and oil palm estates in Melaka and Negri Sembilan States of Peninsula Malaysia, with the co-operation of Dunlop Estates Bhd. Malaysia was chosen since it is one of the few countries in which a population of workers spraying only herbicides may be found and in which the predominant herbicide is paraquat. Furthermore, as the area enjoys conditions of tropical rainfall, spraying continues throughout the year on a daily basis and is not seasonal. Consequently, each sprayman will use considerably greater amounts of paraquat each year than those in temperate climates. No sprayworkers were included in the study from estates where insecticides or other pesticides were known to be used.

The control groups consisted of general plantation workers and latex factory workers. It had been intended to use two groups of estate workers. as controls, one of rubber tappers and oil palm harvesters and the other of general manual workers. It was discovered, however, that some of the tappers and harvesters had been employed in spraying operations and had, therefore, to be excluded. Because of this and the small number of general workers available it was decided to consider both tappers and harvesters together with the general manual workers as a single control group (called general workers). The study was limited to male workers as there were few female spray operators, and their data contain too little information for formal statistical analysis.

The following criteria were used in selection. Spraymen were defined as those who had sprayed a minimum of 1000 hours. General workers were defined as those plantation workers who had no history of spraying and were employed in various manual duties such as tilling, weeding, tapping, and harvesting. Some members of this group had received minimal exposure to paraquat as a result of working in areas of the plantations in which spraying had recently been completed (for discussion see Chester and Woollen ${ }^{8}$ ).

The factory workers were those employed in the estate "factories" where the raw latex is given initial processing to prevent bacterial decomposition and render it fit for travel. None of these workers had any known occupational exposure to paraquat. All three groups had similar social backgrounds and resided in the same estate villages. The workers normally worked an eight-hour day, six days a week, with two weeks' leave each year and an allowance of two weeks' sick leave. The final three groups consisted of 27 spraymen, 24 general workers, and 23 factory workers. Table 1 gives an analysis of the age and racial structure of the whole group.

EXPOSURE TO PARAQUAT AT WORK

The spraying history of each sprayworker was obtained at a preliminary interview that also recorded the extent to which protective clothing was worn during spraying operations; together with any episode of ill-health, such as rashes attributable to occupation. These were later cross-checked with individual medical records. The total amount of paraquat sprayed a year on each estate was obtained from company records and by combining these figures with the spraying record of each man it was possible to produce an estimate of the amount of paraquat each had used. Paraquat is normally sprayed on the estates at a rate of roughly $0.1 \%$ paraquat ion, often in a tank mix with diuron and monosodium methane arsenate and also one of the phenoxy alkylates to ensure a wide spectrum of weed control.

Personal monitoring was also carried out during spraying to gain some estimates of the degree of actual exposure to paraquat during spraying operations. These data will be published later. ${ }^{8}$

Workers generally did not wear any protective clothing during spraying operations (see table 2). Spraymen regularly showered after work and changed their clothes but rarely bothered to wash

Table 1 Age and racial structure of the working groups

\begin{tabular}{|c|c|c|c|c|c|c|c|c|c|c|c|c|c|c|c|c|}
\hline \multirow[t]{2}{*}{$\operatorname{Age}(y r)$} & \multicolumn{4}{|c|}{ Spraymen } & \multicolumn{4}{|c|}{ General workers } & \multicolumn{4}{|c|}{ Factory workers } & \multicolumn{4}{|l|}{ Totals } \\
\hline & Malay & Indian & Chinese & Total & Malay & Indian & Chinese & Total & Malay & Indian & Chinese & Total & Malay & Indian & Chinese & Total \\
\hline $\begin{array}{l}<25 \\
25-34 \\
35-44 \\
\geqslant 45\end{array}$ & $\begin{array}{l}5 \\
4 \\
2 \\
3\end{array}$ & $\begin{array}{l}1 \\
5 \\
3 \\
1\end{array}$ & $\begin{array}{l}1 \\
0 \\
0 \\
2\end{array}$ & $\begin{array}{l}7 \\
9 \\
5 \\
6\end{array}$ & $\begin{array}{l}2 \\
3 \\
2 \\
1\end{array}$ & $\begin{array}{l}2 \\
4 \\
1 \\
2\end{array}$ & $\begin{array}{l}1 \\
3 \\
3 \\
0\end{array}$ & $\begin{array}{r}5 \\
10 \\
6 \\
3\end{array}$ & $\begin{array}{r}11 \\
4 \\
2 \\
0\end{array}$ & $\begin{array}{l}1 \\
1 \\
1 \\
1\end{array}$ & $\begin{array}{l}0 \\
0 \\
0 \\
2\end{array}$ & $\begin{array}{r}12 \\
5 \\
3 \\
3\end{array}$ & $\begin{array}{r}18 \\
11 \\
6 \\
4\end{array}$ & $\begin{array}{r}4 \\
10 \\
5 \\
4\end{array}$ & $\begin{array}{l}2 \\
3 \\
3 \\
4\end{array}$ & $\begin{array}{l}24 \\
24 \\
14 \\
12\end{array}$ \\
\hline Totals & 14 & 10 & 3 & 27 & 8 & 9 & 7 & 24 & 17 & 4 & 2 & 23 & 39 & 23 & 12 & 74 \\
\hline
\end{tabular}


Table 2 Protective clothing worn by spraymen

\begin{tabular}{|c|c|c|}
\hline Type of protection & No & $\%$ \\
\hline $\begin{array}{l}\text { Overalls or plastic apron with rubber boots } \\
\text { Rubber gloves with rubber boots } \\
\text { Rubber boots only } \\
\text { Rubber gloves only } \\
\text { No protection used }\end{array}$ & $\begin{array}{r}1 \\
2 \\
8 \\
1 \\
15\end{array}$ & $\begin{array}{r}3 \cdot 7 \\
7 \cdot 4 \\
29 \cdot 6 \\
3 \cdot 7 \\
55 \cdot 6\end{array}$ \\
\hline Totals & 27 & 100 \\
\hline
\end{tabular}

off minor splashes and only infrequently washed before eating when at work; work clothing was laundered infrequently.

CLINICAL EXAMINATION

All workers were given a full clinical examination, particular attention being paid to the respiratory system and the skin.

CLINICAL MEASUREMENTS

The workers were all examined at one of the estate hospitals, and at roughly the same time, between 1000 and 1200 on several succeeding days. Blood was taken for haematological examination and liver and renal function tests; the specimens were stored in ice and transported to the laboratories in Kuala Lumpur (90 miles away) within three hours. Measurements were completed by 1600 hours the same day. The tests undertaken were as follows:

Respiratory function-Ventilatory function was measured by FVC, $\mathrm{FEV}_{1}$, and $\mathrm{FEV}_{1} \%$ using the standard Vitalograph spirometer and digital display meter. Three readings were taken on each subject, and the highest value achieved was used. Transfer factor (DCO), as an estimate of alveolar diffusion, was measured by a single breath method, using the Hewlett Packard 47404A single breath carbon monoxide diffusion system. The higher of two values was used.

Liver function was determined by estimations of the activity of the following enzymes, using the Hycel Super 17 autoanalyser: serum alanine aminotransferase (ALT) using L-alanine and $a$ ketoglutarate as the substrate and acidic 2,4, dinitrophenyl hydrazine as the colour reagent. Serum aspartate aminotransferase (AST), using $\mathrm{L}$-aspartate and $\alpha$-ketoglutarate as the substrate and fast violet $B$ as the colour reagent, and alkaline phosphatase (ALKP) using magnesium thymolphthalein monophosphate as the substrate and the addition of alkali to induce the colour reaction.

Renal function-Renal function was estimated by determining blood urea nitrogen using the diacetyl/ thiosemicarbazide colorimetric method with the Hycel Super 17 autoanalyser and the determination of serum creatinine using a manual endpoint colorimetric method with picric acid. Urine albumen tests were also performed simply at the time of the first clinical examination by the semiquantitative Ames strip method.

Haematology-Haemoglobin estimations were made by the colorimetric cyanmethaemoglobin method using the Hycel Model 700 automated counter, which also gave red and white cell counts, $\mathrm{PCV}, \mathrm{MCHC}, \mathrm{MCH}$, and MCV. The differential white cell count was performed manually after staining the blood slide with Leishman's stain.

\section{Results}

AMOUNT OF PARAQUAT USED

Each estate taking part in this study used 950-2050 I of Gramoxone (the $20 \%$ agricultural concentrate) a year, depending on area and size of the spray team. This represents an average annual quantity of roughly 3361 of Gramoxone sprayed by each sprayman, equivalent to $67.2 \mathrm{~kg}$ paraquat ion. The mean duration of time the spraymen in this study had worked was 5.3 years, representing a mean of 8696 actual spraying hours per man.

\section{ADVERSE RESPONSES TO PARAQUAT}

There were 11 spraymen who complained of one or more incidents of skin irritation or rashes associated with spraying. These were commonest on hand, legs, or groin. Groin or buttock rashes were commonly associated with a leaking knapsack sprayer that had allowed liquid to run down the back and between the buttocks. Medical records indicated that all cases cleared rapidly in response to local treatment (usually a steroid cream). Although 12 of the spraymen admitted to having had spillages or been splashed, only one case of eye injury had been reported, and this had responded to treatment with no sequelae.

\section{CLINICAL MEASUREMENTS}

To test the effect of occupational exposure to paraquat, sprayers, general workers, and factory workers were compared for each of the 15 clinical measurements. The significance of occupation was tested with allowance made for differences in the distributions of race, age, height, and smoking history among the three groups. This was achieved by fitting multiple regression equations with race, age, height, and smoking history as the independent variables and then by refitting the equations with occupation added as a further independent variable. The decrease in the residual sum of squares thus achieved was tested for significance using an F-test. Details of the independent variables used and the regression equations fitted including all variables are given 
Table 3 Estimated clinical values (Malay). (These values have been estimated using the regression equations in the appendix for a Malay non-smoker, age 30 , height $162.5 \mathrm{~cm}$ )

\begin{tabular}{|c|c|c|c|c|c|c|c|c|c|c|c|}
\hline & $F V C(l)$ & $F E V_{1}(l)$ & $F E V_{1} \%$ & $\begin{array}{l}\text { DCO } \\
(\text { mmol/ } \\
\text { min/kpa })\end{array}$ & $H b(g / d l)$ & $P C V$ & $\begin{array}{l}R B C \\
\text { (millions/ } \\
u l)\end{array}$ & $\begin{array}{l}M C V \\
\left(u m^{3}\right)\end{array}$ & $\begin{array}{l}M C H \\
(p g)\end{array}$ & $\begin{array}{l}\log _{10} \\
W B C\end{array}$ & $\begin{array}{l}W B C \\
(n o / u l)\end{array}$ \\
\hline $\begin{array}{l}\text { Spraymen } \\
\text { General workers } \\
\text { Factory workers }\end{array}$ & $\begin{array}{l}3 \cdot 28 \\
3 \cdot 33 \\
3 \cdot 14\end{array}$ & $\begin{array}{l}2 \cdot 94 \\
2 \cdot 94 \\
2 \cdot 80\end{array}$ & $\begin{array}{l}90 \cdot 0 \\
88 \cdot 3 \\
89 \cdot 0\end{array}$ & $\begin{array}{l}11 \cdot 6 \\
12 \cdot 4 \\
12 \cdot 2\end{array}$ & $\begin{array}{l}14 \cdot 3 \\
15 \cdot 0 \\
14 \cdot 6\end{array}$ & $\begin{array}{l}41 \cdot 6 \\
43 \cdot 3 \\
43 \cdot 5\end{array}$ & $\begin{array}{l}5 \cdot 31 \\
5 \cdot 54 \\
5 \cdot 57\end{array}$ & $\begin{array}{l}77 \cdot 9 \\
77 \cdot 9 \\
77 \cdot 5\end{array}$ & $\begin{array}{l}27 \cdot 0 \\
27 \cdot 0 \\
26 \cdot 3\end{array}$ & $\begin{array}{l}3 \cdot 916 \\
3 \cdot 858 \\
3 \cdot 935\end{array}$ & $\begin{array}{l}8250 \\
7200 \\
86 C 0\end{array}$ \\
\hline $\begin{array}{l}\text { Standard error } \\
\text { (person) } \\
\text { Diiferences between } \\
\text { occupations } \\
\begin{array}{rr}\text { LSD p }=5 \% & \text { S v GW } \\
& \text { S v FW } \\
\text { GW } v \text { FW }\end{array}\end{array}$ & $\begin{array}{l}0.49 \\
p=48 \%\end{array}$ & $\begin{array}{l}0.44 \\
p=51 \%\end{array}$ & $\begin{array}{l}7 \cdot 5 \\
p=73 \%\end{array}$ & $\begin{array}{l}1.9 \\
p=30 \%\end{array}$ & $\begin{array}{l}1 \cdot 3 \\
p=21 \%\end{array}$ & $\begin{array}{l}3 \cdot 5 \\
p=13\end{array}$ & $\begin{array}{l}0.50 \\
p=16 \%\end{array}$ & $\begin{array}{c}5 \cdot 2 \\
p=96\end{array}$ & $\begin{array}{l}2 \cdot 2 \\
p=52\end{array}$ & $\begin{array}{l}0.099 \\
p=5\end{array}$ & \\
\hline
\end{tabular}

\begin{tabular}{|c|c|c|c|c|c|c|c|c|c|c|}
\hline & $\log _{10} A S T$ & $\begin{array}{l}A S T \\
(I U / I)\end{array}$ & $\log _{10} A L T$ & $\begin{array}{l}A L T \\
(I U / I)\end{array}$ & $\begin{array}{l}\log _{10} \\
A L K P\end{array}$ & $\begin{array}{l}A L K P \\
(I U / I)\end{array}$ & $\log _{10} \operatorname{CREAT}$ & $\begin{array}{l}C R E A T \\
(m g / d I)\end{array}$ & $\begin{array}{l}\log _{10} \\
B U N\end{array}$ & $\begin{array}{l}B U N \\
(m g / d l)\end{array}$ \\
\hline $\begin{array}{l}\text { Spraymen } \\
\text { General workers } \\
\text { Factory workers }\end{array}$ & $\begin{array}{l}1 \cdot 315 \\
1 \cdot 286 \\
1 \cdot 345\end{array}$ & $\begin{array}{l}20 \cdot 7 \\
19 \cdot 3 \\
22 \cdot 1\end{array}$ & $\begin{array}{l}1 \cdot 597 \\
1 \cdot 561 \\
1 \cdot 167\end{array}$ & $\begin{array}{l}39 \cdot 5 \\
36 \cdot 4 \\
14 \cdot 7\end{array}$ & $\begin{array}{l}1 \cdot 510 \\
1 \cdot 463 \\
1 \cdot 599\end{array}$ & $\begin{array}{l}32 \cdot 4 \\
29 \cdot 0 \\
39 \cdot 7\end{array}$ & $\begin{array}{r}-0.013 \\
-0.075 \\
0.025\end{array}$ & $\begin{array}{l}0.97 \\
0.84 \\
1.06\end{array}$ & $\begin{array}{l}1 \cdot 031 \\
1 \cdot 023 \\
1 \cdot 107\end{array}$ & $\begin{array}{l}10 \cdot 7 \\
10 \cdot 5 \\
12 \cdot 8\end{array}$ \\
\hline $\begin{array}{l}\begin{array}{l}\text { Standard error } \\
\text { (person) }\end{array} \\
\text { Differences between } \\
\text { occupations } \\
\begin{array}{rr}\text { LSD p }=5 \% & \text { S v GW } \\
& \text { S v FW } \\
\text { GW v FW }\end{array}\end{array}$ & $\begin{array}{l}0 \cdot 153 \\
p=51 \%\end{array}$ & & $\begin{array}{l}0.227 \\
p<0.01 \% \\
0.134 \\
0.134 \\
0.144\end{array}$ & & $\begin{array}{l}0.115 \\
p=0.3 \% \\
0.068 \\
0.068 \\
0.073\end{array}$ & & $\begin{array}{l}0.113 \\
p=3 . \\
0.067 \\
0.067 \\
0.072\end{array}$ & & $\begin{array}{l}0.103 \\
p=2.8 \% \\
0.060 \\
0.061 \\
0.065\end{array}$ & \\
\hline
\end{tabular}

Table 4 Estimated clinical values (Indians). (These values have been estimated using the regression equations in the uppendix for an Indian, non-smoker, aged 30 , height $162.5 \mathrm{~cm}$ )

\begin{tabular}{|c|c|c|c|c|c|c|c|c|c|c|c|}
\hline & $F V C(l)$ & $F E V_{1}(l)$ & $F E V_{1} \%$ & $\begin{array}{l}\text { DCO } \\
(m m o l / \\
\min / k p a)\end{array}$ & $H b(g / d l)$ & $P C V$ & $\begin{array}{l}R B C \\
\text { (millions/ } \\
u l)\end{array}$ & $\begin{array}{l}M C V \\
\left(u m^{3}\right)\end{array}$ & $\begin{array}{l}M C H \\
(p g)\end{array}$ & $\begin{array}{l}\log _{10} \\
W B C\end{array}$ & $\begin{array}{l}W B C \\
(n o / u l)\end{array}$ \\
\hline $\begin{array}{l}\text { Spraymen } \\
\text { General workers } \\
\text { Factory workers }\end{array}$ & $\begin{array}{l}3 \cdot 12 \\
3 \cdot 17 \\
2 \cdot 98\end{array}$ & $\begin{array}{l}2 \cdot 73 \\
2 \cdot 73 \\
2 \cdot 59\end{array}$ & $\begin{array}{l}88 \cdot 2 \\
86 \cdot 5 \\
87 \cdot 2\end{array}$ & $\begin{array}{l}10 \cdot 2 \\
11 \cdot 0 \\
10 \cdot 8\end{array}$ & $\begin{array}{l}14 \cdot 1 \\
14 \cdot 8 \\
14 \cdot 4\end{array}$ & $\begin{array}{l}40 \cdot 2 \\
41 \cdot 9 \\
42 \cdot 1\end{array}$ & $\begin{array}{l}5 \cdot 21 \\
5 \cdot 44 \\
5 \cdot 47\end{array}$ & $\begin{array}{l}77 \cdot 0 \\
77 \cdot 0 \\
76 \cdot 5\end{array}$ & $\begin{array}{l}27 \cdot 2 \\
27 \cdot 2 \\
26 \cdot 5\end{array}$ & $\begin{array}{l}3.954 \\
3.895 \\
3.973\end{array}$ & $\begin{array}{l}9000 \\
7850 \\
9400\end{array}$ \\
\hline $\begin{array}{l}\text { Standard error } \\
\text { (person) } \\
\text { Differences between } \\
\text { occupations } \\
\begin{aligned} & \text { LSD p }=5 \% \text { S v GW } \\
& \text { S v FW } \\
& \text { GW v FW }\end{aligned}\end{array}$ & $\begin{array}{l}0.49 \\
p=48^{\circ}\end{array}$ & $\begin{array}{l}0.44 \\
p=51 \%\end{array}$ & $\begin{array}{l}7 \cdot 5 \\
p=73 \%\end{array}$ & $\begin{array}{l}1.9 \\
p=30 \%\end{array}$ & $\begin{array}{l}1 \cdot 3 \\
p=21 \%\end{array}$ & $\begin{array}{l}3 \cdot 5 \\
p=13\end{array}$ & $\begin{array}{l}0.50 \\
p=16 \%\end{array}$ & $\begin{array}{c}5 \cdot 2 \\
p=96\end{array}$ & $\begin{array}{c}2 \cdot 2 \\
p=52\end{array}$ & $\begin{array}{l}0.099 \\
p=5\end{array}$ & \\
\hline
\end{tabular}

\begin{tabular}{|c|c|c|c|c|c|c|c|c|c|c|}
\hline & $\log _{10} A S T$ & $\begin{array}{l}A S T \\
(I U / I)\end{array}$ & $\log _{10} A L T$ & $\begin{array}{l}A L T \\
(I U / l)\end{array}$ & $\begin{array}{l}\log _{10} \\
A L K P\end{array}$ & $\begin{array}{l}A L K P \\
(I U / I)\end{array}$ & $\begin{array}{l}\log _{10} \\
C R E A T\end{array}$ & $\begin{array}{l}\text { CREAT } \\
(m g / d l)\end{array}$ & $\begin{array}{l}\log _{10} \\
B U N\end{array}$ & $\begin{array}{l}B U N \\
(m g / d l)\end{array}$ \\
\hline $\begin{array}{l}\text { Spraymen } \\
\text { General workers } \\
\text { Factory workers }\end{array}$ & $\begin{array}{l}1 \cdot 362 \\
1 \cdot 333 \\
1 \cdot 392\end{array}$ & $\begin{array}{l}23 \cdot 0 \\
21 \cdot 5 \\
24 \cdot 7\end{array}$ & $\begin{array}{l}1 \cdot 771 \\
1 \cdot 734 \\
1 \cdot 341\end{array}$ & $\begin{array}{l}59 \cdot 0 \\
54 \cdot 2 \\
21 \cdot 9\end{array}$ & $\begin{array}{l}1 \cdot 487 \\
1 \cdot 439 \\
1 \cdot 576\end{array}$ & $\begin{array}{l}30 \cdot 7 \\
27 \cdot 5 \\
37 \cdot 7\end{array}$ & $\begin{array}{r}0.055 \\
-0.006 \\
0.094\end{array}$ & $\begin{array}{l}1 \cdot 14 \\
0 \cdot 99 \\
1 \cdot 24\end{array}$ & $\begin{array}{l}1 \cdot 005 \\
0 \cdot 997 \\
1 \cdot 081\end{array}$ & $\begin{array}{r}10 \cdot 1 \\
9 \cdot 9 \\
12 \cdot 1\end{array}$ \\
\hline $\begin{array}{l}\text { Standard error } \\
\text { (person) } \\
\text { Differences between } \\
\text { occupation } \\
\begin{aligned} & \text { LSD p }=5 \% \text { S v GW } \\
& \text { S v FW } \\
& \text { GW v FW }\end{aligned}\end{array}$ & $\begin{array}{l}0 \cdot 153 \\
p=51 \%\end{array}$ & & $\begin{array}{l}0.227 \\
p<0.01 \% \\
0.134 \\
0.134 \\
0.144\end{array}$ & & $\begin{array}{l}0.115 \\
p=0.3 \% \\
0.068 \\
0.068 \\
0.073\end{array}$ & & $\begin{array}{c}0.113 \\
p=3.4 \% \\
0.067 \\
0.067 \\
0.072\end{array}$ & & $\begin{array}{l}0.103 \\
p=2.8 \% \\
0.060 \\
0.061 \\
0.065\end{array}$ & \\
\hline
\end{tabular}


Table 5 Estimated clinical values (Chinese). (These values have been estimated using the regression equations in the appendix for a Chinese, non-smoker, age 30 , height $162.5 \mathrm{~cm}$ )

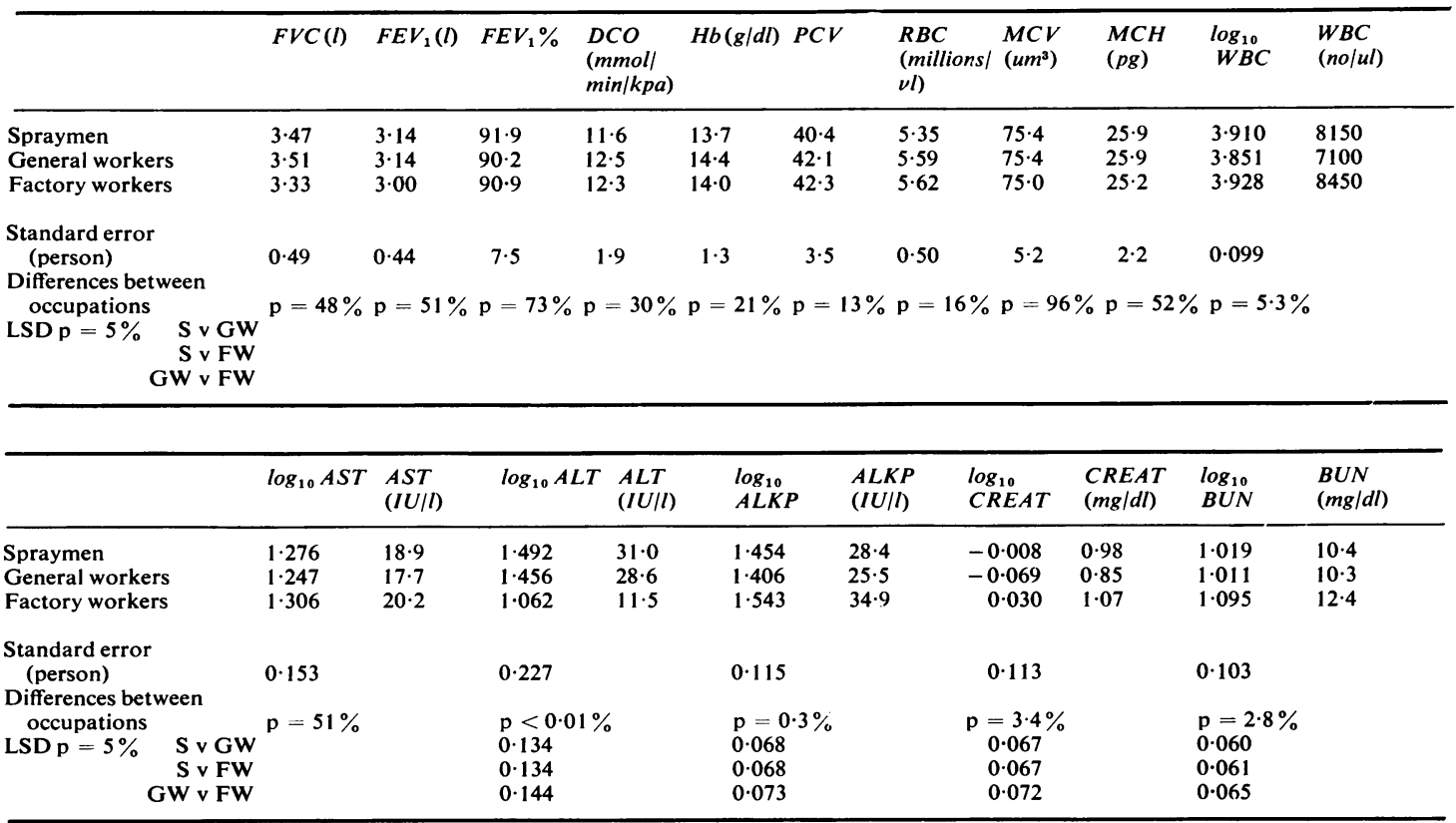

in the appendix. Estimates of the effect of occupation on the clinical measurements may be obtained from these regression equations-for instance, if a sprayer, general worker, and factory worker had the same race, age, height, and smoking history then the sprayer would be expected to have an FVC value 0.139 higher than the factory worker, 0.048 lower than the general worker, and the general worker $0 \cdot 187$ higher than the factory worker. Tables 3,4 , and 5 show the estimated values for each of the occupations for Malay, Indian, and Chinese men aged 30, height $162.5 \mathrm{~cm}$, and non-smokers. The tables show the significance of the differences between the occupations (the probability level for the F-test). The standard error (person) is a measure of the deviation of an actual observation from the regression equation. The LSD $p=5 \%$ is given when differences between occupations are significant at the $5 \%$ probability level. If the estimates for two groups of workers differ by more than the LSD this suggests a significant occupational effect.

No significant differences could be shown for the respiratory or haematological indices. Significant differences, however, were found for both liver and renal measurements, and in each case it was the factory workers who differed from both spraymen and general workers. Concentrations of both serum creatinine and blood urea nitrogen were significantly higher in this group, as was the concentration of serum ALK activity. The concentration of serum ALT activity, however, was significantly lower in factory workers than the other two groups. All group means fell within the concentrations quoted as normal by the laboratory undertaking the estimations.

Further investigations into the effect of spraying on Dco and $\mathrm{Hb}$ estimations were carried out by correlating the residuals of both $\mathrm{DCO}$ and $\mathrm{Hb}$ from the regression equations in the appendix with log total number of spraying hours. In neither case was the correlation statistically significant. All values relating to erythrocytes were lower than corresponding Caucasian values.

Age and height were significant variables with $\mathrm{FEV}_{1}$, and FVC measurements and age was a significant variable in respect of $\mathrm{FEV}_{1} \%$ and Dco values. A racial trend appeared to exist with Dco values, Indians showing slightly lower values. The mean values and range, however, were comparable with figures obtained from "normal" Caucasians.

Smoking did not appear as a significant variable in the respiratory measurements, which is almost certainly related to the fact that of the 74 subjects, 
only nine smoked more than 15 a day and only two more than 25 a day. Thirty were non-smokers, and 22 smoked from 1 to 10 cigarettes a day.

\section{Discussion}

The data obtained from this study indicate that the health risks associated with long-term spraying of paraquat are negligible, despite the large quantities used.

The prominence of lung damage in cases of paraquat poisoning by ingestion had led to concern being expressed about the possibility of such damage developing in spray operators exposed to paraquat. Malone et $a l^{9}$ and Fitzgerald et al ${ }^{10}$ have both stated that such damage may occur. More recently Levin et $a^{7}$ have reported reduction in pulmonary function, particularly the assessment of alveolar diffusion after what appears to have been exposure to abnormally high concentrations of paraquat. This present study of workers exposed daily for long periods and using large quantities of paraquat failed to show any differences in lung function between sprayworkers and the two groups of controls. The range of values for ventilatory function did not differ in the three groups, and the mean values were not significantly different. The values were also in close agreement with the "normal" values obtained in other studies of Asian subjects, ${ }^{11-13}$ suggesting that the groups under study represented a "normal" population. In none of the three groups of workers did occupation have any significant effect on ventilatory function, although, in agreement with all previously published work, FEV $_{1}$ and FVC values were related to both age and height. As expected, the values are consistently lower than those for Caucasians of equivalent age and height. ${ }^{14}$

The assessment of alveolar diffusing capacity by the use of single breath carbon monoxide diffusion measurements (Dco) also showed no differences among the three working groups. This is thought to be the first time that alveolar diffusion has been measured in such an Asian population, and no comparisons could be made with previously obtained normal values. The range of values, however, is very close to those reported from studies of Caucasian subjects. ${ }^{15-17}$

Concern has also been expressed that exposure to paraquat may induce blood changes as there are isolated instances of blood dyscrasias in cases of clinical paraquat poisoning. ${ }^{18}$ There has never been any evidence, however, that exposure to paraquat under normal working conditions has any effects on the blood. We found no significant differences among the three working groups. Values associated with the red cell series were slightly lower than would have been expected in a comparable Caucasian group, but this is a general finding and reflects dietary habits and the effects of helminth infection (Kaur, unpublished observations), which were indicated by consistently high eosinophil counts in a large proportion of the population studied.

The effects of paraquat on both liver and renal function have been observed in severe poisoning after ingestion from the first cases reported. ${ }^{19}$ Raised blood urea nitrogen and raised levels of serum ALKP and AST and regular features even in nonfatal poisoning cases. No such abnormalities were found in the group of sprayworkers. The factory workers, however, did show some variation of both renal and liver function tests. These did not fall

\section{Appendix}

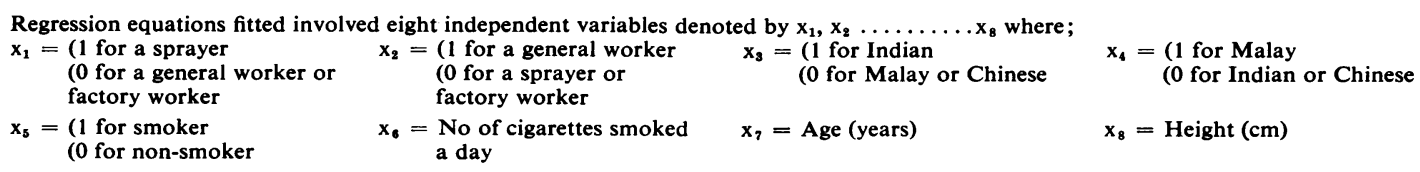

Derived regression equations are set out as follows:

\begin{tabular}{|c|c|c|c|c|c|c|c|c|c|c|c|}
\hline $\begin{array}{l}\text { VC } \\
E V_{1} \\
E V \% \\
C O \\
\mathrm{Ib} \\
\mathrm{CV} \\
\mathrm{BC} \\
\mathrm{ICV} \\
\mathrm{lCH} \\
\mathrm{g}_{10} \text { WBC } \\
\mathrm{g}_{10} \text { AST } \\
\mathrm{g}_{10} \text { ALT } \\
\mathrm{g}_{10} \text { ALKP } \\
\mathrm{g}_{10} \text { CREAT } \\
\mathrm{g}_{10} \text { BUN }\end{array}$ & $\begin{array}{l}= \\
= \\
= \\
= \\
= \\
= \\
= \\
= \\
= \\
= \\
= \\
= \\
= \\
=\end{array}$ & $\begin{array}{c}-4 \cdot 448 \\
-3 \cdot 837 \\
88 \cdot 53 \\
5 \cdot 16 \\
13 \cdot 04 \\
37 \cdot 61 \\
5 \cdot 599 \\
69 \cdot 85 \\
24 \cdot 11 \\
4 \cdot 2115 \\
1 \cdot 9974 \\
0 \cdot 3417 \\
2 \cdot 0994 \\
0 \cdot 5176 \\
0 \cdot 6444\end{array}$ & $\begin{array}{l}+0.139 x_{1} \\
+0.141 x_{1} \\
+1.04 x_{1} \\
-0.63 x_{1} \\
-0.34 x_{1} \\
-1.90 x_{1} \\
-0.262 x_{1} \\
+0.43 x_{1} \\
+0.71 x_{1} \\
-0.0186 x_{1} \\
-0.0300 x_{1} \\
+0.4302 x_{1} \\
-0.0889 x_{1} \\
-0.0383 x_{1} \\
-0.0757 x_{1}\end{array}$ & $\begin{array}{l}+0.187 x_{2} \\
+0.140 x_{2} \\
-0.70 x_{2} \\
+0.22 x_{2} \\
+0.33 x_{2} \\
-0.18 x_{2} \\
-0.028 x_{2} \\
+0.44 x_{2} \\
+0.71 x_{2} \\
-0.0771 x_{2} \\
-0.0596 x_{2} \\
+0.3937 x_{2} \\
-0.1366 x_{2} \\
-0.0994 x_{2} \\
-0.0839 x_{2}\end{array}$ & $\begin{array}{l}-0.346 \mathrm{x}_{3} \\
-0.413 \mathrm{x}_{3} \\
-3.78 \mathrm{x}_{3} \\
-1.44 \mathrm{x}_{3} \\
+0.38 \mathrm{x}_{3} \\
-0.24 \mathrm{x}_{3} \\
-0.148 \mathrm{x}_{3} \\
+1.59 \mathrm{x}_{3} \\
+1.28 \mathrm{x}_{3} \\
+0.0442 \mathrm{x}_{3} \\
+0.0859 \mathrm{x}_{3} \\
+0.2790 \mathrm{x}_{3} \\
+0.0336 \mathrm{x}_{3} \\
+0.0632 \mathrm{x}_{3} \\
-0.0145 \mathrm{x}_{3}\end{array}$ & $\begin{array}{l}-0.185 x_{4} \\
-0.201 x_{4} \\
-1.93 x_{4} \\
-0.03 x_{4} \\
+0.57 x_{4} \\
+1.15 x_{4} \\
-0.044 x_{4} \\
+2.53 x_{4} \\
+1.09 x_{4} \\
+0.0065 x_{4} \\
+0.0390 x_{4} \\
+0.1052 x_{4} \\
+0.0568 x_{4} \\
-0.0057 x_{4} \\
+0.0118 x_{4}\end{array}$ & $\begin{array}{l}+0.434 x_{5} \\
+0.395 x_{5} \\
+0.23 x_{5} \\
-0.99 x_{5} \\
+0.36 x_{5} \\
+1.18 x_{5} \\
-0.267 x_{5} \\
+6.47 x_{5} \\
+2.00 x_{5} \\
+0.0533 x_{5} \\
-0.0606 x_{5} \\
-0.1726 x_{5} \\
-0.1265 x_{5} \\
+0.0479 x_{5} \\
+0.0279 x_{5}\end{array}$ & $\begin{array}{l}-0.0115 x_{6} \\
-0.0160 x_{6} \\
-0.193 x_{6} \\
+0.030 x_{6} \\
-0.029 x_{6} \\
-0.082 x_{6} \\
+0.0105 x_{6} \\
-0.322 x_{6} \\
-0.110 x_{6} \\
-0.00416 x_{6} \\
+0.00299 x_{6} \\
+0.00679 x_{6} \\
+0.00338 x_{6} \\
-0.00163 x_{6} \\
+0.00180 x_{6}\end{array}$ & $\begin{array}{l}-0.0156 x_{7} \\
-0.0218 x_{7} \\
-0.254 x_{7} \\
-0.105 x_{7} \\
-0.003 x_{7} \\
-0.014 x_{7} \\
-0.0084 x_{7} \\
+0.109 x_{7} \\
+0.039 x_{7} \\
-0.00225 x_{7} \\
-0.00061 x_{7} \\
+0.00344 x_{7} \\
-0.00185 x_{7} \\
-0.00031 x_{7} \\
+0.00133 x_{7}\end{array}$ & $\begin{array}{l}+0.0507 x_{8} \\
+0.0461 x_{8} \\
+0.062 x_{8} \\
+0.063 x_{8} \\
+0.007 x_{8} \\
+0.032 x_{8} \\
+0.016 x_{8} \\
+0.011 x_{8} \\
-0.0003 x_{8} \\
-0.00133 x_{8} \\
-0.00414 x_{8} \\
+0.00379 x_{8} \\
-0.00308 x_{8} \\
-0.00294 x_{8} \\
+0.00253 x_{8}\end{array}$ & $\begin{array}{r}27 \\
9 \\
57 \\
34 \\
23 \\
23\end{array}$ \\
\hline
\end{tabular}


outside the range of normal values for the laboratory.

The few instances of local skin lesions from poor spraying techniques and accidents is indicative of the high levels of training and supervision on the Dunlop Estates. No cases of nose bleeding were recorded and only one case of eye injury, which recovered with no sequelae. The evidence of this study indicates that paraquat spraying does not give rise to any serious health problems when properly used.

The active co-operation and help of $\mathrm{Mr}$ Martin Collier of Dunlop Estates Bhd and the various estate managers and the hospital staff, especially of Regent Estate Hospital, is acknowledged with grateful thanks. We also thank Dr A K Seth of ICI Ltd, Plant Protection Division, who acted as the indefatigable liaison officer throughout the study and also Drs M S Rose and I Carney, who with other members of ICI Ltd, Central Toxicology Laboratory, gave valuable help and assistance at the planning and commissioning stage. Mr N Smith and his staff of ICI (Malaysia) gave valuable help in arranging the study, especially in clearing equipment through customs and other administrative matters. Thanks are also due to Dr $\mathrm{H}$ Kaur and the staff of Computer Medic Lab Sdn Bhd for undertaking the blood analyses.

\section{References}

${ }^{1}$ Swan AAB. Exposure of spray operators to paraquat. Br J Ind Med 1969;26:322-9.

${ }^{2}$ Hogarty C. Exposure of spray operators to paraquat. Dublin: Institute for Industrial Research and Standards, 1975.

${ }^{3}$ Staiff DC, Comer SW, Armstrong JJ, Wolfe HR. Exposure to the herbicide paraquat. Bull Environ Contam Toxicol 1975;14:334-40.
${ }^{4}$ Howard JK. A clinical survey of paraquat formulation workers. Br J Ind Med 1979;36:220-3.

${ }^{5}$ Howard JK. Paraquat, a review of worker exposure in normal usage. J Soc Occup Med 1980;30:6-11.

- Peoples SA, Maddy KT, Riddle LC. Human health problems associated with the herbicide paraquat. Los Angeles: California Dept of Food and Agriculture, 1977.

${ }^{7}$ Levin PJ, Klaff LJ, Rose AG, Ferguson AD. Pulmonary effects of contact exposure to paraquat: a clinical and experimental study. Thorax 1979;34:150-60.

${ }^{8}$ Chester G, Woollen BH. A study of the occupational exposure to paraquat of Malaysian plantation workers. Br J Ind Med.

- Malone JDG, Carmody M, Keogh B, O'Dwyer WF. Paraquat poisoning, a review of 19 cases. Journal of the Irish Medical Association 1971;64:59-68.

${ }^{10}$ Fitzgerald GR, Barniville G, Black J, Silk B, Carmody M, O'Dwyer WF. Paraquat poisoning in agricultural workers. Journal of the Irish Medical Association 1978; $71: 336-42$.

11 Milledge JS. Vital capacity and forced expiratory volumes in one second in South Indian men. Ind J Chest Dis Allied Sci 1965;7:97-102.

12 Da Costa JL, Coh BK. Prediction nomograms for lung function measurements in adult Chinese. Singapore Med $J 1971 ; 12: 193-8$.

13 Zee KO, Chew PK. Ventilatory function in normal industrial Malay workers in Singapore. Singapore Med $J$ 1976;17:242-7.

14 Berglund E, Birath G, Bjure J, Grimby G, Kjellmer I, Sangvist L. Spirometric studies in normal subjects between 7 and 70 years of age. Acta Med Scand 1963; 173:185-91.

15 Ogilvie CM, Forster RE, Blakemore WI, Morton JW. A standardised breath holding technique for the clinical measurements of the diffusing capacity of the lung for carbon monoxide. J Clin Invest 1957;36:1-7.

${ }^{16}$ Daly JJ, Roe JW. Serial measurements of the pulmonary diffusing capacity for carbon monoxide in a group of men employed in industry. Thorax 1962;17:298-302.

12 Newman F, Smalling BF, Thomson ML. Effect of exercise, body, and lung size on carbon monoxide diffusion in athletes and non-athletes. J Appl Physiol 1962;17: 649-55.

${ }^{18}$ Lautenschlager J, Grabensee B, Pottgin W. Isolierte aplastische Anamie nach Paraquatvergiftung. Blut 1974; 28:221.

19 Bullivant CM. Accidental poisoning by paraquat: report of two cases in man. Br Med J 1966;i:1272-3. 